\title{
Supplemental folic acid in pregnancy and childhood cancer risk
}

\author{
Jan Helge Seglem Mortensen ${ }^{1,2}$, Nina Øyen ${ }^{1,3}$, Tatiana Fomina ${ }^{1}$, Mads Melbye ${ }^{4,5,6}$, Steinar Tretli ${ }^{7}$, Stein Emil Vollset ${ }^{1,8}$ \\ and Tone Bjørge ${ }^{\star, 1,7}$ \\ ${ }^{1}$ Department of Global Public Health and Primary Care, University of Bergen, Kalfarveien 31, Bergen N-5018, Norway; \\ ${ }^{2}$ Department of Obstetrics and Gynecology, Haukeland University Hospital, Bergen, Norway; ${ }^{3}$ Center for Medical Genetics and \\ Molecular Medicine, Haukeland University Hospital, Bergen, Norway; ${ }^{4}$ Department of Epidemiology Research, National Health \\ Surveillance and Research, Statens Serum Institut, Copenhagen, Denmark; ${ }^{5}$ Department of Clinical Medicine, University of \\ Copenhagen, Copenhagen, Denmark; 'Department of Medicine, Stanford University School of Medicine, Stanford, CA, USA; \\ ${ }^{7}$ Cancer Registry of Norway, Oslo, Norway and ${ }^{8}$ Norwegian Institute of Public Health, Oslo, Norway
}

Background: We investigated the association between supplemental folic acid in pregnancy and childhood cancer in a nationwide study of 687406 live births in Norway, 1999-2010, and 799 children diagnosed later with cancer.

Methods: Adjusted hazard ratios (HRs) compared cancer risk in children by approximated periconceptional folic acid levels (folic acid tablets and multivitamins $(0.6 \mathrm{mg})$, only folic acid $(0.4 \mathrm{mg})$, only multivitamins $(0.2 \mathrm{mg})$ ) and cancer risk in unexposed.

Results: Any folic acid levels were not associated with leukemia (e.g., high-level folic acid HR 1.25; 95\% Cl 0.89-1.76, $P_{\text {Trend }} 0.20$ ), lymphoma (HR 0.96; 95\% Cl 0.42-2.21, $P_{\text {Trend }} 0.51$ ), central nervous system tumours (HR 0.68; 95\% Cl 0.42-1.10, $P_{\text {Trend }} 0.32$ ), neuroblastoma (HR 1.05; 95\% Cl 0.53-2.06, $P_{\text {Trend }} 0.85$ ), Wilms' tumour (HR 1.16; 95\% Cl 0.52-2.58, $P_{\text {Trend }} 0.76$ ), or soft-tissue tumours (HR 0.77; 95\% Cl 0.34-1.75, $\left.P_{\text {Trend }} 0.90\right)$.

Conclusions: Folic acid supplementation was not associated with risk of major childhood cancers.

Health authorities in many countries recommend women planning pregnancy to take folic acid before and during pregnancy to reduce offspring risk of neural tube defects (SACN, 2006). A large number of countries also fortify flour with folic acid (CDC, 2008). Mandatory food fortification with folic acid is debated in some countries because of the suggested cancer risk in adults (Kim, 2004; Mason et al, 2007; Smith et al, 2008). However, in case-control studies on children, cancer risks (leukemia, brain tumours) were reduced if the mother had been exposed to perigestational maternal folic acid supplementation (Thompson et al, 2001; Milne et al, 2010; Milne et al, 2012; Metayer et al, 2014). And, in ecological studies from Canada and the United States of America, the childhood cancer incidence (Wilms' tumour, primitive neuroectodermal tumours, neuroblastoma) has been reduced after mandatory folic acid flour fortification (French et al, 2003; Grupp et al, 2011; Linabery et al, 2012).
The aim of our study was to investigate the association between maternal intake of folic acid supplementation in pregnancy and offspring risk of childhood cancer in a nation-wide cohort study in Norway.

\section{MATERIALS AND METHODS}

Data sources. The unique personal identification number assigned to all Norwegian residents enabled linkage of information between the Medical Birth Registry of Norway (MBRN) (Irgens, 2000), the Cancer Registry of Norway (CRN) (Larsen et al, 2009), and the Norwegian National Education Database that holds information on all individuals' education (Kinge et al, 2015).

Folic acid and multivitamin supplementation exposure. Folic acid and multivitamin supplementation use has been registered in

*Correspondence: Professor T Bjørge; E-mail: Tone.Bjorge@uib.no 
the MBRN since December 1998. The registration form uses check boxes with the items 'folic acid before pregnancy', 'folic acid during pregnancy', 'multivitamins before pregnancy', and 'multivitamins during pregnancy'. During the study period, the folic acid content was $0.4 \mathrm{mg}$ in folic acid supplements and approximately $0.2 \mathrm{mg}$ in multivitamin supplements. Children were defined as exposed to folic acid if their mothers used folic acid supplements and/or multivitamins before and/or during pregnancy. Maternal folic acid intake was categorised by increasing folic acid content; no supplement use $(0 \mathrm{mg})$, only multivitamins (approximately $0.2 \mathrm{mg}$ ), only folic acid supplements $(0.4 \mathrm{mg})$, or intake of both folic acid supplements and multivitamins (approximately $0.6 \mathrm{mg}$ ).

Childhood cancer. Childhood cancer cases were identified through linkage with CRN. For each child, the first cancer diagnosis was used. The childhood cancers were categorised according to the International Classification of Childhood Cancer, version 3, which is based on ICD-O-3 (Steliarova-Foucher et al, 2005).

Study cohort. The study cohort consisted of all live births in Norway, 1 January 1999 through 31 December 2010 (excluding children with mothers with a prebirth cancer diagnosis (3371)), with follow-up until a cancer diagnosis, emigration, death, or 31 December 2010.

Statistical analysis. Risk of childhood cancers in children exposed to maternal folic acid and/or multivitamin supplements was compared with cancer risk in unexposed children and estimated with hazard ratios (HRs) using Cox proportional hazards regression models with time since birth as the time variable, adjusting for a priori selected covariates associated with maternal folic acid use and childhood cancer risk; that is, birth order $(1,2$, $\geqslant 3$ ), maternal smoking (never, sometimes, $\leqslant 10$ cigarettes daily, $>10$ cigarettes daily, daily smoking of unknown amount), maternal and paternal age $(<25,25-34, \geqslant 35$ years), and maternal and paternal education (compulsory, intermediate, tertiary). $P$-values for linear trend were calculated for folic acid exposure levels $(0 \mathrm{mg}, 0.2 \mathrm{mg}, 0.4 \mathrm{mg}, 0.6 \mathrm{mg}$ ). Statistical analyses were performed in STATA version 14 (STATA, 2015).

Ethics. The Regional Committee for Medical and Health Research Ethics of Western Norway approved the study.

\section{RESULTS}

Among 687406 children included in the study, 799 developed cancer. The mean follow-up time was 6 years (range 0.04-12 years), constituting 4052679 person-years (Table 1). Among all births, $4 \%$ were multiple births, and $2 \%$ were born after assisted reproductive technology. Mean maternal age at childbirth was 29 years (range 13-55 years). The proportion of children exposed to perigestational supplementation increased in the study period, 1999-2010; intake of folic acid changed from $18 \%$ to $69 \%$ and multivitamins from $19 \%$ to $42 \%$.

About $67 \%$ of all cancers were diagnosed within the first 3 years of life (Table 2). Leukemia and central nervous system (CNS) tumours accounted for $57 \%$ of the cases. We performed analyses for the six most frequent childhood cancer types (leukemia, lymphoma, CNS tumours, neuroblastoma, Wilms' tumour, soft tissue tumours) (Table 3). There was no change in childhood leukemia risk by maternal use of multivitamins only (HR 1.23; 95\% CI $0.75-2.01$ ), folic acid use only (HR 1.13; 95\% CI $0.79-1.63$ ), or combined folic acid and multivitamin use (HR 1.25; 95\% CI 0.89-1.76), as compared with no supplement use $\left(P_{\text {Trend }} 0.20\right)$. Similarly, there were no associations between CNS tumours and different levels of maternal folic acid intake; multivitamins only (HR 1.08; 95\% CI 0.60-1.94), folic acid use only (HR 1.18; 95\% CI $0.78-1.78$ ), or combined folic acid and multivitamin use
Table 1. Characteristics of the study population of 687406 live births, Norway, 1999-2010

\begin{tabular}{|l|c|c|c|c|}
\hline Characteristics & Cohort (n) & $\begin{array}{c}\text { Person- } \\
\text { years }\end{array}$ & $\%$ & $\begin{array}{c}\text { Cancer } \\
\text { cases (n) }\end{array}$ \\
\hline Children & 687406 & 4052679 & 100 & 799 \\
\hline Sex & 352604 & 2077322 & 51 & 423 \\
\hline Boys & 334802 & 1975357 & 49 & 376 \\
Girls & \multicolumn{5}{|l}{} \\
\hline Gestational age (weeks) & 46682 & 271770 & 7 & 60 \\
\hline$<37$ & 587197 & 3447416 & 85 & 670 \\
$37-41$ & 48830 & 307613 & 8 & 62 \\
$\geqslant 42$ & 4697 & 25881 & 1 & 7 \\
Missing
\end{tabular}

\begin{tabular}{|l|c|c|c|c|}
\hline \multicolumn{5}{|l|}{ Birth weight (g) } \\
\hline$<2500$ & 33804 & 191809 & 5 & 39 \\
$2500-3999$ & 516075 & 3008163 & 74 & 587 \\
$\geqslant 4000$ & 136760 & 847264 & 21 & 173 \\
Missing & 767 & 5443 & 0 & 0 \\
\hline Birth order & 284468 & 1651442 & 41 & 339 \\
\hline 1 & 244834 & 1446964 & 36 & 281 \\
2 & 158104 & 954274 & 24 & 179 \\
$\geqslant 3$
\end{tabular}

\begin{tabular}{|l|c|c|c|c|}
\hline \multicolumn{5}{|l|}{ Maternal age at child birth, years } \\
\hline$<25$ & 117065 & 697604 & 17 & 133 \\
$25-34$ & 452481 & 2709049 & 67 & 539 \\
$\geqslant 35$ & 117860 & 646026 & 16 & 127
\end{tabular}

Paternal age at child birth, years

\begin{tabular}{|l|c|c|c|c|}
\hline$<25$ & 52776 & 312202 & 8 & 65 \\
$25-34$ & 396496 & 2406027 & 59 & 468 \\
$\geqslant 35$ & 231836 & 1307428 & 32 & 257 \\
Missing & 6298 & 27023 & 1 & 9
\end{tabular}

\section{Maternal education $^{a}$}

\begin{tabular}{|l|c|c|c|c|}
\hline Compulsory & 128452 & 782418 & 19 & 148 \\
Intermediate & 232745 & 1475123 & 36 & 288 \\
Tertiary & 299871 & 1662622 & 41 & 340 \\
Missing & 26338 & 132516 & 3 & 23 \\
\hline
\end{tabular}

\section{Paternal education $^{a}$}

\begin{tabular}{|l|c|c|c|c|}
\hline Compulsory & 129537 & 779208 & 19 & 142 \\
Intermediate & 301918 & 1842424 & 45 & 373 \\
Tertiary & 227910 & 1297762 & 32 & 251 \\
Missing & 28041 & 133286 & 3 & 33 \\
\hline
\end{tabular}

Maternal smoking

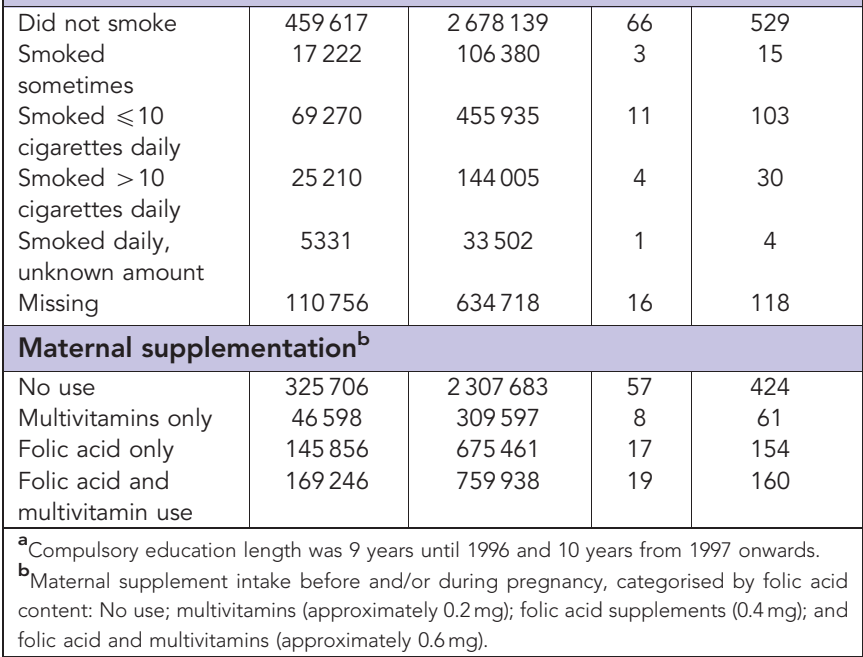

(HR 0.68; 95\% CI 0.42-1.10), as compared with no supplement use ( $P_{\text {Trend }} 0.32$ ). The HRs of the other frequent childhood cancer types (lymphoma, neuroblastoma, Wilms' tumour, soft tissue tumours) did not change for different levels of folic acid exposure. Adding birth year to adjustment models showed no substantial 
Table 2. Children with first-time childhood cancer $(n=799)$ by age at diagnosis, year of diagnosis, and major cancer types (ICCC-3), identified among 687406 livebirths, Norway, 1999-2010

\begin{tabular}{|c|c|c|}
\hline & Cancer cases & $\%$ \\
\hline \multicolumn{3}{|l|}{ Age at cancer diagnosis (years) } \\
\hline$<2$ & 326 & 41 \\
\hline $2-3$ & 211 & 26 \\
\hline $4-5$ & 150 & 19 \\
\hline$\geqslant 6$ & 112 & 14 \\
\hline \multicolumn{3}{|l|}{ Year of cancer diagnosis } \\
\hline 1999-2001 & 59 & 7 \\
\hline 2002-2004 & 172 & 22 \\
\hline 2005-2007 & 239 & 30 \\
\hline 2008-2010 & 329 & 41 \\
\hline \multicolumn{3}{|l|}{ Cancer types (ICCC-3) } \\
\hline $\begin{array}{l}\text { I Leukemias, myeloproliferative diseases, and } \\
\text { myelodysplastic diseases }\end{array}$ & 268 & 34 \\
\hline Lymphoid leukemia & 208 & \\
\hline Acute myeloid leukemias & 45 & \\
\hline $\begin{array}{l}\text { II Lymphomas and reticuloendothelial } \\
\text { neoplasms }\end{array}$ & 42 & 5 \\
\hline $\begin{array}{l}\text { III CNS and miscellaneous intracranial and } \\
\text { intraspinal neoplasms }\end{array}$ & 185 & 23 \\
\hline Ependymoma & 26 & \\
\hline Astrocytoma & 79 & \\
\hline $\begin{array}{l}\text { Intracranial and intraspinal embryonal } \\
\text { tumours }\end{array}$ & 50 & \\
\hline $\begin{array}{l}\text { IV Neuroblastoma and other peripheral nervous } \\
\text { cell tumours }\end{array}$ & 72 & 9 \\
\hline Neuroblastoma and ganglioneuroblastoma & 71 & \\
\hline VI Renal tumours & 53 & 7 \\
\hline Wilms' tumour & 52 & \\
\hline IX Soft tissue and other extraosseous sarcomas & 64 & 8 \\
\hline Rhabdomyosarcoma & 24 & \\
\hline Other specified soft tissue sarcomas & 28 & \\
\hline Other cancers & 115 & 14 \\
\hline Total & 799 & 100 \\
\hline
\end{tabular}

changes in the risk estimates for neither cancer types. And excluding 867 children with Down syndrome from the analyses did not change the HR estimates for specific cancers.

\section{DISCUSSION}

In a nation-wide cohort study of all live births, estimated maternal intakes of multivitamins, folic acid, or combined intake of these supplements were not associated with childhood cancer.

Our results of no association between periconceptional folic acid supplementation and major childhood cancers are in discordance with case-control studies showing inverse associations between self-reported folic acid use and acute lymphoblastic leukemia (ALL) (Thompson et al, 2001; Milne et al, 2010; Metayer et al, 2014) and CNS tumours (Milne et al, 2012).

A recent large international collaborating study, including $>7000$ children with acute leukemia and 11000 controls, found reduced risks of ALL and acute myeloid leukemia (AML) after maternal intake of folic acid supplements. And these reduced risks of ALL and AML did not vary by timing of the supplementation exposure (preconception, pregnancy, or pregnancy trimester) (Metayer et al, 2014). However, an Australian study found weak evidence of a reduced risk of ALL from folate supplementation before pregnancy, but no reduced risk from use during pregnancy (Milne et al, 2010). Also, another Australian study reported on an inverse association of childhood brain tumours and folic acid supplementation before and possibly also during pregnancy (Milne et al, 2012). In our study, a further stratification of the exposure data into preconceptional use and use during pregnancy was not feasable due to the limited statistical power of the analyses.

The strengths of our study include using comprehensive data from population-based registries covering the entire Norwegian population. To our knowledge, Norway is the only country where individual-level information on periconceptional folic acid and multivitamin intake has been collected for the entire birth population since 1999. All incident cancer cases have been reported to the Cancer Registry of Norway since 1952 (Larsen et al, 2009). And information on supplement use was collected before cancer diagnosis precluding recall bias.

Table 3. Hazard ratios (HRs) with $95 \%$ confidence intervals $(95 \% \mathrm{Cl}$ ) of childhood cancer by perigestational supplementation of folic acid and/or multivitamins, among 687406 children, Norway, 1999-2010

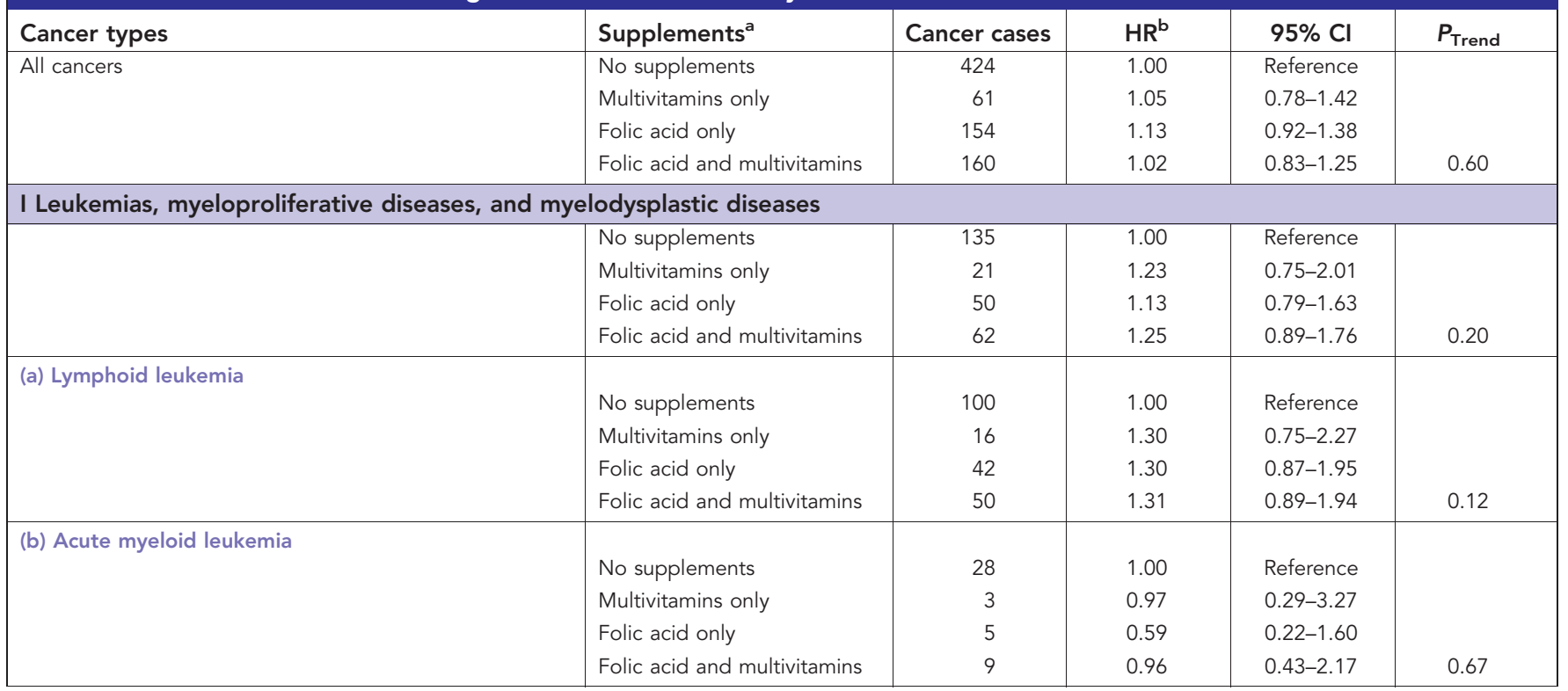




\section{Table 3. (Continued)}

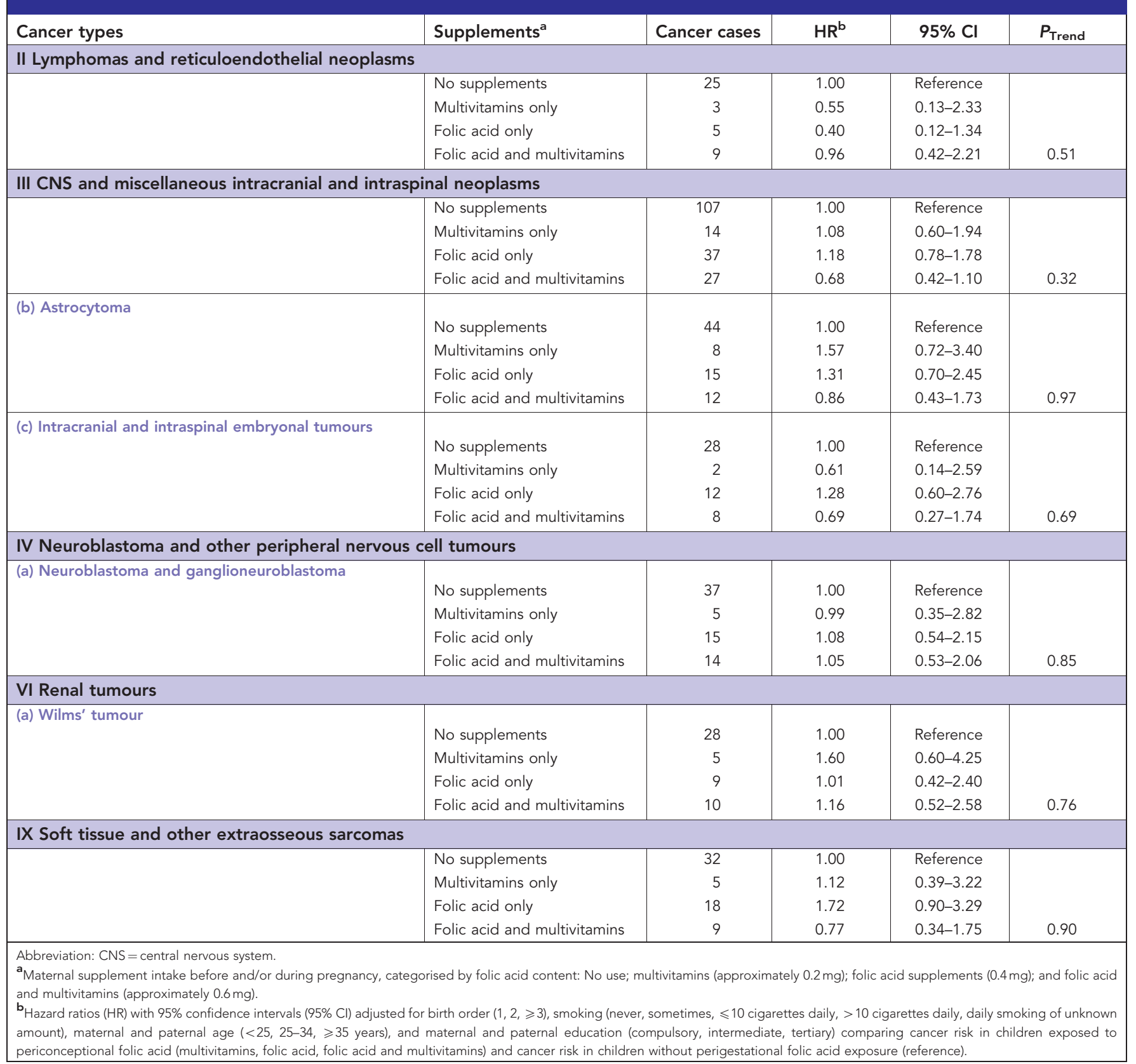

The study had some limitations. Even though our cohort was large, the numbers of several childhood cancer types were relatively low, which may limit the statistical power of our findings. The follow-up time of study participants were on average 6 years, and our results could only be generalised to younger children. Maternal folic acid intake could have been misclassified; in the beginning of the study period, folic acid users were under-reported to the MBRN (Nilsen et al, 2009). A possible misclassification of folic acid dose (independent of cancer risk) would bias risk estimates towards the null value and, in theory, could have concealed an association between folic acid intake and childhood cancer risk. Information on maternal smoking was missing for $16 \%$ of the births; however, HR estimates adjusting for maternal smoking were similar to HRs without smoking adjustments. Although we did not have information on dietary folate, residual confounding by dietary folate is less likely. In pregnant women, maternal plasma levels of serum folate is strongly related to intake of folic acid supplements (Bjorke-Monsen et al, 2013). And in other studies of maternal intake of folic acid supplements and offspring outcomes (oral clefts, autism), adjustment for dietary folate did not change overall risk estimates (Wilcox et al, 2007; Suren et al, 2013). We could not adjust for mother's weight and height, physical activity, diet, use of alcohol, or use of contraceptive pills, as these covariates were not available in the MBRN.

In conclusion, we found no association between maternal supplemental folic acid intake before and/or during pregnancy and risk of leukemia, lymphomas, CNS tumours, neuroblastoma, Wilms' tumour, or soft tissue tumours among younger children.

\section{ACKNOWLEDGEMENTS}

This study was supported by the Norwegian Cancer Society and the Western Norway Regional Health Authority (911629) to Dr Nina Øyen. 


\section{CONFLICT OF INTEREST}

The authors declare no conflict of interest.

\section{REFERENCES}

Bjorke-Monsen AL, Roth C, Magnus P, Midttun O, Nilsen RM, Reichborn-Kjennerud T, Stoltenberg C, Susser E, Vollset SE, Ueland PM (2013) Maternal B vitamin status in pregnancy week 18 according to reported use of folic acid supplements. Mol Nutr Food Res 57(4): 645-652.

CDC (2008) Trends in wheat-flour fortification with folic acid and ironworldwide, 2004 and 2007. MMWR Morb Mortal Wkly Rep 57: 8-10.

French AE, Grant R, Weitzman S, Ray JG, Vermeulen MJ, Sung L, Greenberg M, Koren G (2003) Folic acid food fortification is associated with a decline in neuroblastoma. Clin Pharmacol Ther 74(3): 288-294.

Grupp SG, Greenberg ML, Ray JG, Busto U, Lanctot KL, Nulman I, Koren G (2011) Pediatric cancer rates after universal folic acid flour fortification in Ontario. J Clin Pharmacol 51(1): 60-65.

Irgens LM (2000) The Medical Birth Registry of Norway. Epidemiological research and surveillance throughout 30 years. Acta Obstet Gynecol Scand 79(6): 435-439.

Kim YI (2004) Will mandatory folic acid fortification prevent or promote cancer? Am J Clin Nutr 80(5): 1123-1128.

Kinge JM, Steingrimsdottir OA, Moe JO, Skirbekk V, Naess O, Strand BH (2015) Educational differences in life expectancy over five decades among the oldest old in Norway. Age Ageing 44(6): 1040-1045.

Larsen IK, Smastuen M, Johannesen TB, Langmark F, Parkin DM, Bray F, Moller B (2009) Data quality at the Cancer Registry of Norway: an overview of comparability, completeness, validity and timeliness. Eur J Cancer 45(7): 1218-1231.

Linabery AM, Johnson KJ, Ross JA (2012) Childhood cancer incidence trends in association with US folic acid fortification (1986-2008). Pediatrics 129(6): 1125-1133.

Mason JB, Dickstein A, Jacques PF, Haggarty P, Selhub J, Dallal G, Rosenberg IH (2007) A temporal association between folic acid fortification and an increase in colorectal cancer rates may be illuminating important biological principles: a hypothesis. Cancer Epidemiol Biomarkers Prev 16(7): 1325-1329.

Metayer C, Milne E, Dockerty JD, Clavel J, Pombo-de-Oliveira MS, Wesseling C, Spector LG, Schuz J, Petridou E, Ezzat S, Armstrong BK, Rudant J, Koifman S, Kaatsch P, Moschovi M, Rashed WM, Selvin S, McCauley K, Hung RJ, Kang AY, Infante-Rivard C (2014) Maternal supplementation with folic acid and other vitamins and risk of leukemia in offspring: a
Childhood Leukemia International Consortium study. Epidemiology 25(6): 811-822.

Milne E, Greenop KR, Bower C, Miller M, van Bockxmeer FM, Scott RJ, de Klerk NH, Ashton LJ, Gottardo NG, Armstrong BK, Aus CBTC (2012) Maternal use of folic acid and other supplements and risk of childhood brain tumors. Cancer Epidemiol Biomarkers Prev 21(11): 1933-1941.

Milne E, Royle JA, Miller M, Bower C, de Klerk NH, Bailey HD, van Bockxmeer F, Attia J, Scott RJ, Norris MD, Haber M, Thompson JR, Fritschi L, Marshall GM, Armstrong BK (2010) Maternal folate and other vitamin supplementation during pregnancy and risk of acute lymphoblastic leukemia in the offspring. Int J Cancer 126(11): 2690-2699.

Nilsen RM, Vollset SE, Gjessing HK, Skjaerven R, Melve KK, Schreuder P, Alsaker ER, Haug K, Daltveit AK, Magnus P (2009) Self-selection and bias in a large prospective pregnancy cohort in Norway. Paediatr Perinat Epidemiol 23(6): 597-608.

SACN (2006) Folate and Disease Prevention. TSO (The Stationery Office), Scientific Advisory Committe on Nutrition: London, UK.

Smith AD, Kim YI, Refsum H (2008) Is folic acid good for everyone? Am J Clin Nutr 87(3): 517-533.

STATA (2015) Stata Statistical Software: Release 14. StataCorp LP: College Station, TX, USA.

Steliarova-Foucher E, Stiller C, Lacour B, Kaatsch P (2005) International Classification of Childhood Cancer, third edition. Cancer 103(7): 1457-1467.

Suren P, Roth C, Bresnahan M, Haugen M, Hornig M, Hirtz D, Lie KK, Lipkin WI, Magnus P, Reichborn-Kjennerud T, Schjolberg S, Davey Smith G, Oyen AS, Susser E, Stoltenberg C (2013) Association between maternal use of folic acid supplements and risk of autism spectrum disorders in children. JAMA 309(6): 570-577.

Thompson JR, Gerald PF, Willoughby ML, Armstrong BK (2001) Maternal folate supplementation in pregnancy and protection against acute lymphoblastic leukaemia in childhood: a case-control study. Lancet 358(9297): 1935-1940.

Wilcox AJ, Lie RT, Solvoll K, Taylor J, McConnaughey DR, Abyholm F, Vindenes H, Vollset SE, Drevon CA (2007) Folic acid supplements and risk of facial clefts: national population based case-control study. BMJ 334(7591): 464

This work is published under the standard license to publish agreement. After 12 months the work will become freely available and the license terms will switch to a Creative Commons AttributionNonCommercial-Share Alike 4.0 Unported License. 